\title{
Correction to: Development of an efficient bioreactor system for delivering foreign proteins secreted from liver into eggs with a vitellogenin signal in medaka Oryzias latipes
}

\author{
Yu Murakami ${ }^{1} \cdot$ Tomohisa Horibe $^{2}$ - Masato Kinoshita ${ }^{1}$
}

Published online: 4 April 2020

(c) The Author(s) 2020, corrected publication March 2020

\section{Correction to: Fisheries Science (2019) 85:677-685 https://doi.org/10.1007/s12562-019-01320-4}

The article "Development of an efficient bioreactor system for delivering foreign proteins secreted from liver into eggs with a vitellogenin signal in medaka Oryzias latipes", written by Yu Murakami, Tomohisa Horibe and Masato Kinoshita was originally published electronically on the publisher's internet portal on 21 May 2019 without open access. After publication in volume [85], issue [4], page [677-685] with the author(s)' decision to opt for Open Choice the copyright of the article changed on 31st March 2020 to () The Author(s) 2020 and the article is forthwith distributed under a Creative Commons Attribution 4.0 International License (https://creativecommons.org/licenses/by/4.0/), which permits use, sharing, adaptation, distribution and reproduction in any medium or format, as long as you give appropriate credit to the original author(s) and the source, provide a link to the Creative Commons licence, and indicate if changes were made.

Open Access This article is licensed under a Creative Commons Attribution 4.0 International License, which permits use, sharing, adaptation, distribution and reproduction in any medium or format, as long as you give appropriate credit to the original author(s) and the source, provide a link to the Creative Commons licence, and indicate if changes were made. The images or other third party material in this article are included in the article's Creative Commons licence, unless indicated otherwise in a credit line to the material. If material is not included in the article's Creative Commons licence and your intended use is not permitted by statutory regulation or exceeds the permitted use, you will need to obtain permission directly from the copyright holder. To view a copy of this licence, visit http://creativecommons.org/licenses/by/4.0/.

Publisher's Note Springer Nature remains neutral with regard to jurisdictional claims in published maps and institutional affiliations.
Masato Kinoshita

kinoshit@kais.kyoto

1 Division of Applied Bioscience, Graduate

School of Agriculture, Kyoto University,

Kitashirakawa-Oiwake-cho, Sakyo-ku, Kyoto 606-8502,

Japan

2 2Department of Pharmacoepidemiology, Graduate

School of Medicine and Public Health, Kyoto University,

Yoshida-Konoe-cho, Kyoto 606-8501, Japan 